DEGRADASI SENYAWA CARBARYL DALAM PESTISIDA SEVIN 85 S SECARA SONOLISIS, OZONOUISIS DAN SONOZOLISIS

\title{
T E S IS
}

Oreh:

MEGA GEMALA 07.207003

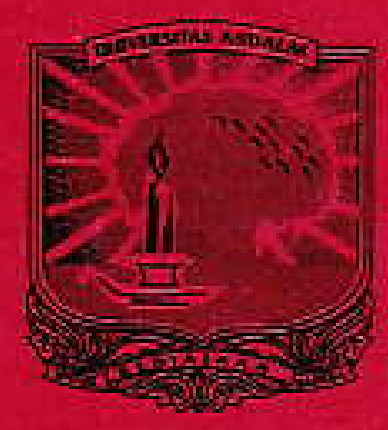

PROGRAM PASCASARJANA UNIVERSITAS ANDALAS 2009 


\title{
DEGRADASI SENYAWA CARBARYL DALAM PESTISIDA SEVIN $85 \mathrm{~S}$ SECARA SONOLISIS, OZONOLISIS DAN SONOZOLISIS
}

\author{
Oleh : Mega Ciemala \\ (Di bawah bimbingan Salni dan Hamzar Suyani)
}

\section{RINGKASAN}

Perkembangan yang pesat dibidang ilmu pengetabuan seiring majunya pembangunan dibidang industri serla teknologi telah memacu manusia untuk dapat memenuhi segala kebutuhan hidup demi tercapainya suatu keselamatan. jaminan dan kualitas hidup tinggi. Akan tetapi timbul berbagai permasalahan lingkungan akibat aktivitas manusia dalam usaha pemenuhan kebutuhannya, salah satunya adalah meluasnya penggunaan pestisida yang dapat menimbulkan dampak negatif baik langsung maupun tidak langsung bagi kesehatan manusia dan lingkungan.

Carbaryl adalah salah satu pestisida golongan karbamat yang mempunyai rumus umum $\mathrm{C}_{12} \mathrm{H}_{11} \mathrm{NO}_{2}$ dengan berat molekul 201,23 gimol. Nama kimia dari carbaryl adalah 1-napthyl N-methylcarbamate. Carbaryl berupa padatan yang warnanya berada diantara tak berwarna-putih-abu-abu tergantung kepada kemurniannya. Carbaryl merupakan insektisida untuk mengendalikan hama pada tanaman seperti jagung, kacang tanah, kapas, kedelai, kclapa. kelapa sawit, kopi, lada, tcbu, teh dan tembakau. Carbaryl dijual sebagai pencampur dalam beberapa merk dagang, salah satunya Sevin $85 \mathrm{~S}$. Luasnya penggunaan 


\section{PENDAHULUAN}

\subsection{Latar Belakang}

Perkembangan yang pesat dibidang ilmu pengetahuan seiring majunya pembangunan dibidang industri serta teknologi telah memacu manusia untuk dapat memenuhi segala kebutuban hidup demi tercapainya suatu keselamatan, jaminan dan kualitas hidup tinggi. Akan tetapi timbul berbagai permasalahan lingkungan akibat aktivitas manusia dalam usaha pemenuhan kebutuhannya. seperti meluasnya penggunaan pestisida yang dapat menimbulkan dampak negatif baik langsung maupun tidak langsung bagi kesebatan manusia dan lingkungan.

Berdasarkan Peraturan Pemerintah No, 7 tahun 1973 yang dimaksud dengan pestisida adalah semua zat kimia dan bahan lain serla jasad renik dan virus yang digunakan untuk memberantas atau mencegah lama atau penyakit yang merusak tanaman atau hasil pertanian, memberantas gulma, membunuh atau mengendalikan berbagai hama yang dianggap merugikan atau penyakil yang merusak tanaman, bagian tanaman atau hasil pertanian. Pada umumnya pestisida yang digunakan adalah racun yang berbahaya yang dapat mengancam keselatan manusia., sumber daya hayati dan lingkungan pada umumnya (Sudarmo, 1991).

Penggunaan senyawa organik sintetik baik untuk budidaya tanaman maupun keperluan industri memberikan dampak negatif yaitu tercenarnya sumber daya air. Carbaryl merupakan bahan aktif yang terkandung dalam salah satu jenis insektisida yang dijual sebagai pencampur dalam bebcrapa merek dagang. salah Satunya Sevin 85 S. Senyawa ini digunakan untuk mengendalikan hama pada tanaman jagung. kacang tanah, kapas, kedelai, kelapa, kelapa sawit, kopi, lada. 
tebu, teh dan tembakau. Luasnya penggunaan senyawa carbaryl dibidang pertanian akan menyebabkan semakin banyaknya residu senyawa ini terakumulasi di alam.

Limbah yang mengandung pestisida ini akan dialirkan ke sungai-sungai yang sering digunakan masyarakat untuk keperluan schari-hari. Mengingat besarnya efek negatif yang ditimbulkan oleh toksisitas zat ini, maka perlu dilakukan penelitian untuk mengatasinya. Sclama ini cara umum untuk mengolah air limbah ini adalah dengan pengendapan kimia dan koagulasi. Pengolahan air limbah kimia dengan cara pengendapan kimia membutuhkan biaya yang tidak sedikit, penyerapan limbah oleh karbon aktif. menghasilkan lumpur atau siuclge yang dianggap sebagai limbah yang berbahaya dan membutuhkan perlakuan lcbih lanjut (Kuo dan Ho. 2001).

Pada penelitian ini, dilakukan dekomposisi carbaryl secara sonolisis dengan menggunakan gelombang ultrasonik dan ozonolisis dengan menggunakan ozon $\left(\mathrm{O}_{1}\right)$ selanjutnya dilakukan penggabungan kedua metoda ini (sonolisis dan ozonolisis) yang dinamakan sonozolisis. Sonolisis merupakan salah satu metoda yang digunakan untuk mendegradasi zat organik dalam media air dengan mengunakan getaran ultrasonik yang beroperasi pada frekuensi $20 \mathrm{kJz}-1 \mathrm{MHz}$, dimana dalam prosesnya akan menghasilkan radikal hidroksil dan cfek kavitasi (Stock, et al. 2000). Radikal hidroksil tersebut akan mendekomposisi carbaryl menjadi senyawa yang lebih sederhana. Untuk mendapatkan hasil dekomposisi yang efektif disini ditambalkan $\mathrm{TiO}_{2}$ - anatase sebagai katalis yang telah terbukti mampu mengkatalis dekomposisi senyawa organik. Hasil penelitian sebelumnya (Arief. S, et al, 2007) menunjukkan rhodamin B terdegradasi 90\% dengan

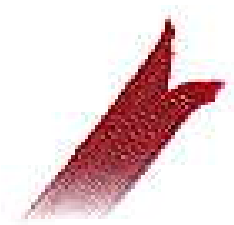




\section{v. KESIMPULAN DAN SARAN}

\subsection{Kesimpulan}

Carbaryl dapat didegradasi dengan menggunakan metoda sonolisis, ozonolisis dan sonozolisis. Degradasi carbaryl $20 \mathrm{mg} / \mathrm{L}$ sccara sonolisis tanpa penambahan $\mathrm{TiO}_{2}$-anatase selama 150 menit pada suhu $45^{\circ} \mathrm{C}$ mencapai persen degradasi $12,66 \%$, sedangkan dengan penambahan $\mathrm{TiO}_{2}$-anatase mencapai persen degradasi $36,68 \%$. Dengan menggunakan metoda ozonolisis, degradasi carbaryl $20 \mathrm{mg} / \mathrm{L}$ selama 90 menit mencapai persen degradasi $48 \%$, dan secara sonozolisis, senyawa carbary/ terdegradasi mencapai $67,28 \%$ selama 75 menit. Dari hasil ini dapat disimpulkan bahwa metoda yang paling efektif untuk mendegradasi senyawa Carbaryl adalah metoda sonozolisis karena dapat mendegradasi dengan persentase yang lebih besar dalam waktu yang lebil singkat..

\section{$5+2$ Saran}

Bagi penclitian selanjutnya disarankan untuk memodifikasi metoda atau parameter agar dapat mencapai persentase degradasi hingga 100\%. Disarankan juga untuk mengidentifikasi produk yang terbentuk dengan metoda HPLC. 


\section{DAFTAR PUSTAKA}

Arif, S., Safni, P.Perdana Roza, 2007. Degradasi Senyawa Rhodamin B Secara Sonolisis dengan Penambahan $\mathrm{TiO}_{2}$ Melalui Proses Sol-Gel. J. Ris. Kim. 1 (1), 64-69

Destaillats, H., T. W. Anderson, M. R. Hoffmann. 2001. Application of Ultrasound in NAPI. Remediation Sonochemical Degradation of TCE in Aqueous Surfactant Solution. J. Environ Sci, Tech, : 3019-3024

Dukkanci, M., G. Gunduz. 2005. Ultrasonic Degradation of Oxalic Acid in Aqueous Solution. J. Utrasonic Sonochemistry : 150 - 155

Era, Y., Safni, Hamzar Suyani. 2008. Degradasi Senyawa Paraquat Dalam Pestisida Gramoxone Secara Fotolisis dengan Penambahan $\mathrm{TiO}_{2}$-Anatase. $J$. Ris. Kim. 2 (1), 94-100

Gunlazuardi, J. 2001. Fotokatalisis Pada Permukaan $\mathrm{TiO}_{2}$ : Aspek Fundamenta] dan Aplikasinya, Seminar Nasional Kimia Fisika. Univ Indonesia.

Hiskia, A, M. Ecke, A. Kokorakis. H. Hennig, E. Papaconstatinou, 2001. Sonolytic, and Photocatalytic Decomposition of Atrazin in Presence of Polyoxometalates. J. Environ. Sci. Tech. 35: 2358-2364.

Nang, J, F. Zhijun, Z. Zhaobang, Z. Xiangdang. 2006. Sonocatalytic Degradationof Methyl Parathion in the Presence of Nanometer and Ordinary Anatase Titanium Dioxide Catalysts and Comparison of Their Sonocatalytic Abilities, Departement of Chemistry, Liaoning University.

Park, H, W. Choi, 2005. Photocatalytic Reaktivities of Nation-Coated $\mathrm{TiO}_{2}$ for The Degradation Charged Organic Compound under UV or Visible Light, $J$. Phys, Chem. B, 109: 11667-116674.

Peller, J, O. Wiest, P.V. Kamat. 2001. Sonolysis of 2,4-Diclorophenoxyacetic Acid in Ageous Solution. Evidence for $\mathrm{OH}$-radical-Mediated Degradation. J. Phys Chem. A. 105;3176-3181.

Ruan. R. Z. Liu, S. Deng,. 2004. Removal of Pesticides Residue in Produce with Ozonated Water Wash. CIGR International Conference Bejjing.

Safni. U. Lukman, F. Febrianti. 2008a. Degradasi Zat Warna Sudan 1 Secara Sonolisis dan Fotolisis Dengan Penambahan $\mathrm{TiO}_{2}$-Anatase, $J$. Ris. Kim. I (2): $164-170$. 